\title{
Shifting the Teaching Beliefs of Preservice Science Teachers About Socioscientific Issues in a Teacher Education Course
}

\author{
Jessica Shuk Ching Leung ${ }^{1}$
}

Received: 9 July 2020 / Accepted: 29 March 2021 / Published online: 15 May 2021

(C) Ministry of Science and Technology, Taiwan 2021

\begin{abstract}
The purpose of this study was to investigate how 22 preservice science teachers' (PSTs') beliefs about teaching socioscientific issues (SSI) changed after experiencing SSI instruction and reflection from both a learner's perspective and a teacher's perspective during a 12-week initial teacher education course. The study also explored the learning experiences associated with these changes. This study was conducted in Hong Kong, where the science, technology, society and environment (STSE) framework has been integrated into the secondary science curriculum but no SSI instruction is provided. Data were collected through learning tasks completed by the participants: (a) curriculum designs (pre-, mid- and post-course), (b) lesson plans (mid- and postcourse) and (c) weekly reflective journals. Six profiles characterising teaching beliefs about SSI emerged from the data analysis. Qualitative analysis showed that the teaching beliefs of the PSTs had shifted from the traditional view that SSI should not be covered in science education to embracing SSI teaching. Three illustrative cases were used to capture key learning experiences and explore how these had led to a change in beliefs over time. These cases explained how PSTs' reflection on the why, what and how of teaching SSI to students can shape their beliefs about teaching SSI. The results have implications for the development of a closer alignment between PST beliefs and the SSI paradigm.
\end{abstract}

Keywords Preservice teachers $\cdot$ Reflection $\cdot$ Socioscientific issues $\cdot$ Teaching beliefs

Socioscientific issues (SSI) are ethically complex, ill-structured and controversial social issues with conceptual or procedural links to science. They often involve contested knowledge and have multiple possible solutions (Zeidler, 2014). By their very nature,

Jessica Shuk Ching Leung

leungscj@hku.hk

1 Faculty of Education, The University of Hong Kong, Pokfulam Road, Hong Kong, Hong Kong 
SSI go beyond the realm of science and require "the consideration of ethical issues and construction of moral judgements about scientific topics via social interaction and discourse' (Zeidler \& Keefer, 2003, p. 8). In today's era of rapid advances in science, citizens are often confronted with SSI that profoundly affect everyday life, e.g. climate change and the COVID-19 pandemic; in many cases, it is not possible for an individual to wait until consensus is reached before deciding on a course of action (Leung \& Cheng, 2021). SSIbased instruction can engage students as citizens and encourage them to proactively make informed judgements about SSI (Bencze, Sperling, \& Carter, 2012). As pointed out in a seminal paper by Hodson (2003), conventional science teaching typically deals with 'established and secure knowledge, whilst contested knowledge, multiple solutions, controversy and ethics have been excluded' (p. 664). In contrast, fully fledged SSI teaching often entails leading students to consider multiple perspectives and worldviews in their argumentation or decision-making, including the exploration of ethical aspects of issues (Cheng \& Leung, in press). It requires a deep restructuring of conventional science education practices (Zeidler, Applebaum, \& Sadler, 2011).

Within the science-education research community, emphasis has increasingly shifted from an exclusively content-centred science curriculum to one that incorporates the study of SSI. This is seen in the growing interest in moving from Vision I scientific literacy, which looks at the internal 'products and processes of science itself' (Roberts, 2007, p. 730), to Vision II, which looks beyond the inner workings of science to 'situations in which science can legitimately be seen to play a role in other human affairs' (Roberts, 2007, p. 729), and finally to Vision III, which is underpinned by 'a politicised vision of science education aiming at dialogical emancipation, critical global citizenship, and socioecojustice' (Sjöström \& Eilks, 2018, p. 82). If the aim of scientific literacy is to empower citizens to participate actively in an ever-changing society shaped by science, then the mere acknowledgement of science's internal agenda (Vision I) is far from adequate. Vision III is distinct from Vision II due to its emphasis on scientific engagement (Yore, 2012) and knowing-in-action (Aikenhead, 2007). Operationalising Vision III in science classrooms requires SSI to be the drivers of the curriculum (Sjöström \& Eilks, 2018). The interest in shifting from an exclusively content-centred science curriculum to one that incorporates SSI has been seen in initiatives such as Promoting Attainment of Responsible Research and Innovation in Science Education (www.parrise.eu), a European Union project involving 18 universities across 11 countries that explores pedagogies bringing together inquiry-based science education, SSI and citizenship education. It has also been exemplified in new curricular and instructional frameworks, such as Science \& Technology Education Promoting Wellbeing for Individuals, Societies \& Environments (www.stepwiser.ca), which teaches young people to examine science and technology critically and act to address associated problems of concern to them. However, this growing interest may not be reflected in actual school science practice. For instance, studies in Argentina (Furman, Taylor, Luzuriaga, \& Podestá, 2020), Hong Kong (Leung, Wong, \& Chan, 2020), Israel (Cohen, Zafrani, \& Yarden, 2020) and the United Kingdom (Amos, Knippels, \& Levinson, 2020) have suggested that teachers remain attached to a view of science as facts rather than a field in which citizens can actively participate; that is, they tend to be oriented towards Vision I (Evagorou \& Dillon, 2020). Addressing this misalignment with the SSI paradigm is important.

This study was conducted in Hong Kong, where the science, technology, society and environment (STSE) framework has been integrated into secondary science curriculum 
documents (Curriculum Development Council, 2017) but SSI instruction is not provided. 'SSI' is a broad term that subsumes the concept of STSE and goes beyond it. In Hong Kong, science teachers comply with the STSE framework by highlighting the connections between science and society. However, 'the ethical dimensions of science, the moral reasoning of the child, and the emotional development of the student' (Zeidler, Walker, Ackett, \& Simmons, 2002, p. 344) emphasised in SSI instruction are rarely, if ever, included in the local science curriculum. As a result, SSI are not normally covered in local science teacher education. The course described in this study was unique among science teacher education programmes in Hong Kong. Even in countries that include a focus on SSI in their science curricula, the inclusion of SSI in teaching has not been adequately substantiated in teacher education (e.g. Genel \& Topçu, 2016; Labate, 2007) or in classroom practice (e.g. Ekborg, Ottander, Silfver, \& Simon, 2013; Tidemand \& Nielsen, 2017). Hence, the findings of this study also have implications for science education beyond the Hong Kong context. Teachers' beliefs play an important role in shaping their teaching practices in the classroom. Lee and Witz (2009) indicated that teachers' beliefs and values may lead them to choose to discuss SSI. This implies that in the Hong Kong context, teachers who acknowledge the value of SSI may independently decide to incorporate SSI into their teaching despite their absence from the science curriculum. This study investigated preservice science teachers' (PSTs') beliefs about teaching SSI and how their beliefs changed during an initial science teacher education course. PSTs were chosen as the target participants, because teachers' values and beliefs change little once they have become established after several years of teaching (Witz \& Lee, 2009).

\section{Theoretical Framework and Related Research}

This section starts with a discussion of the theoretical ideal of the SSI paradigm, followed by the belief framework that guided the research design in this study. It ends with a summary of previous research on teachers' beliefs about SSI teaching.

\section{Theoretical Ideal of the SSI Paradigm}

Theoretical discussions and empirical work have suggested that incorporating SSI into science curriculums (a) cultivates students' values, helping them to become global citizens (Kim, Ko, \& Lee, 2020); (b) supports students' skills development; (c) serves as an effective context to support student learning about the nature of science (NOS) (Karisan \& Zeidler, 2017); and (d) facilitates students' learning of science content knowledge (Sadler, Romine, \& Topçu, 2016). These results suggest that SSI can be a vehicle for developing students' values, skills, understanding of the NOS, and conceptual understanding of science. At the same time, these outcomes support the consideration of SSI as a learning goal in itself, as they are essential for making informed judgements about such issues. The synergistic relationship between SSI and these curriculum components is further discussed below. First, values are driving forces that guide individuals to make informed judgements and act responsibly in relation to SSI (Lee, Chang, Choi, Kim, \& Zeidler, 2012). SSI-based instruction effectively facilitates values development (Fowler, Zeidler, \& Sadler, 2009). Discussions of SSI allow 
students to consider the moral and ethical aspects of science and their consequences for society (Zeidler, Sadler, Applebaum, \& Callahan, 2009), and to make decisions that incorporate moral judgements. Second, SSI-based instruction facilitates the development of student skills, such as critical thinking (Wang, Chen, Lin, Huang, \& Hong, 2017), decision-making (Fang, Hsu, \& Lin, 2019), argumentation (Dawson \& Carson, 2020), informal reasoning (Karpudewan \& Roth, 2018), and perspective taking (Newton \& Zeidler, 2020), which are crucial for making informed judgements and participating in discussions about SSI. Third, understanding the NOS has been recognised by many to inform judgements about SSI (Leung, 2020a; Leung, Wong, \& Yung, 2017). Conversely, SSI can be used as a basis for explicit discussions of the NOS through discourse and inquiry when formulating decisions (Nuangchalerm, 2010) and provide a suitable context for a better understanding of the NOS (Zeidler, 2014). Fourth, the use of SSI has been shown to facilitate science content learning (Sadler et al., 2016). SSI-based instruction encourages students to consider their understanding of the science content knowledge underlying an SSI, which can in turn inform their judgements on the issue (Zeidler et al., 2009). In summary, there is a synergistic relationship between SSI and these curriculum components. Our prior work suggested that it is important to address this relationship in initial teacher education courses aimed at preparing PSTs for SSI teaching. The failure to do so may lead PSTs to continue viewing SSI as subsidiary to the NOS and science content knowledge, affecting in turn whether and how SSI is implemented in science classrooms (Leung et al., 2020). To effect a shift from this relative lack of emphasis on SSI to an acknowledgment of the synergistic relationship, this study drew on the literature on teachers' beliefs for its course design, data analysis and discussion of results.

\section{Belief Framework}

Teachers' beliefs play an important role in shaping their practices in the classroom (e.g. Bryan \& Atwater, 2002). Studies on teachers' beliefs have used various definitions, frameworks and methodologies (Jones \& Carter, 2007), indicating the messy nature of the belief construct (Pajares, 1992). Beliefs have been described as subjective claims that an individual accepts or wants to be true (e.g. Pajares, 1992), and as individually held conceptions of what should be or is preferable (e.g. Basturkmen, Loewen, \& Ellis, 2004). As seen in the exhaustive review of research on the topic by Fives and Buehl (2012), teachers' beliefs have been underscored as important because they are filters for interpretation (e.g. Hermans, van Braak, \& Van Keer, 2008; Pajares, 1992), frames for conceptualising tasks (e.g. Rimm-Kaufman, Storm, Sawyer, Pianta, \& LaParo , 2006) and guides for action (e.g. Hancock \& Gallard, 2004). As filters, beliefs influence the interpretation of content relevance and whether it is worth discussing with students. When teachers' belief filters lead them to see certain events or content as relevant to students, the stage is set for beliefs to frame a task. As soon as a task is conceptualised through belief frames, beliefs guide actions. In view of this, this study characterised beliefs as a teacher's conceptions of objects, people, events and relationships in a system to which he/she is committed and which filter, frame and guide his/her pedagogical decisions. The above framework can be used to speculate about the possible pedagogical effects of teacher education about SSI. First, for such teacher education to have an impact on practice, the introduction of SSI to teachers must be accompanied by their belief that SSI are worth teaching. Without this 
belief, teachers may filter SSI out of their teaching agenda, leading to a traditional approach to science teaching. Second, even among teachers who do believe that SSI are worth teaching, their beliefs may lead them to frame SSI as mere instruments for facilitating students' science content learning or for generating class interest. Such would be a contentcentred interpretation of SSI (a term borrowed from Tidemand \& Nielsen, 2017). These teachers would be unlikely to adopt fully fledged SSI teaching that takes the consideration of SSI to be a learning goal in itself. Finally, among teachers whose beliefs are aligned with the theoretical ideal, the training they have received about SSI would probably be retained rather than filtered out. Their beliefs would frame the SSI-related tasks they design in ways that support the development of the values and skills required to analyse SSI, empowering students to make informed judgements about SSI. As a result, the theoretical ideal of the SSI paradigm would be more likely to be actualised in their teaching practice.

Beliefs are not always consciously held; they may become explicit through practice. Therefore, in this study, instead of probing the participants' professed beliefs (i.e. what teachers say) using interview protocols or questionnaires, teachers' intended beliefs (i.e. their intentions through planning) were explored through an analysis of their planned actions, which are precursors to actions (Ajzen \& Fishbein, 1973). The participants' planned actions were assessed through a curriculum design task that probed their beliefs about whether SSI should be given a place in the science curriculum (belief filter) and why (belief frame), and a lesson planning task that explored their beliefs about how SSI should be taught (belief guide). These tasks were administered at various time points to capture changes in their beliefs.

\section{Teachers' Beliefs About Teaching SSI}

Most science teachers endorse making teaching socially relevant, yet when they are asked about implementing such a curriculum, they provide many reasons for not doing so (Aikenhead, 2006). This corroborates with the inconsistency between teachers' endorsement of teaching SSI and their failure to implement SSI teaching. In a study examining teachers' perceptions of SSI teaching, which was conducted with 102 preservice biology teachers in Turkey, Kara (2012) revealed that PSTs generally believe that biology students should be taught about SSI. Similarly, in a study involving 37 science teachers in the U.S., the participants viewed that it is important to teach social issues in science classes. However, only some considered teaching social issues as important as teaching science content (Pedersen \& Totten, 2001). Such endorsement of SSI cannot be assumed as equivalent to fully fledged SSI teaching. In a qualitative study based on group interviews with 11 teachers and an open-ended questionnaire with 100 teachers, Tidemand and Nielsen (2017) reported that Danish biology teachers generally adopted a content-centred interpretation of the SSI paradigm. Similarly, a study involving 55 teachers in Sweden found that teachers often covered SSI to stimulate student interest and introduce scientific content, but their ethical aspects were rarely discussed (Ekborg et al., 2013). Echoing these results, in a study of 52 PSTs in Thailand, few reported covering SSI in their teaching (Pitiporntapin, Yutakom, \& Sadler, 2016). Among those who did, their SSI coverage was limited to introducing a lesson, in which SSI-related videos were used to stimulate student interest. These results confirm those of previous research, which have consistently shown that teaching science content (Vision I) remains the priority among science teachers (e.g. 
Sadler, Amirshokoohi, Kazempour, \& Allspaw, 2006). Even if science teachers wish to incorporate SSI into their teaching, they are often limited by external constraints, such as a lack of instructional time and the unavailability of relevant materials (e.g. Lee, Abd-El-Khalick, \& Choi, 2006), insufficient knowledge of social ramifications (Simonneaux \& Simonneaux, 2009) and unfamiliarity with teaching practices (Ekborg et al., 2013) and assessment strategies (Tidemand \& Nielsen, 2017). Studies of the cocreation of materials (e.g. Friedrichsen, Sadler, \& Zangori, 2020), pedagogical content knowledge for SSI (PCK-SSI; e.g. Bayram-Jacobs et al., 2019) and self-efficacy in teaching SSI (e.g. Yahaya, Zain, \& Karpudewan, 2015) have in part helped teachers to overcome these constraints. As Forbes and Davis (2008) pointed out, 'preservice teachers' capacity to craft effective teaching practice in the context of SSI is only as powerful as their willingness to fully engage in the ethical and normative dimensions of such topics' (p. 849). Teachers' reluctance to include ethical aspects in their SSI teaching is likely to dissuade them from adopting effective teaching practices even when they are equipped to do so. Research efforts to help teachers develop SSI-based teaching will probably be in vain if teachers' internal beliefs (e.g. willingness to incorporate the ethical aspects of SSI) are not addressed, and the inconsistency highlighted by Aikenhead (2006) will probably remain unresolved.

Echoing prior findings, most of the PSTs who participated in another Hong Kong study responded in the affirmative when they were asked whether SSI should be part of the science curriculum and whether it is important to spend instructional time on SSI. However, their reasons for integrating SSI teaching into the curriculum largely pertained to a content-centred interpretation of SSI or an understanding of SSI as a vehicle for developing students' skills and understanding of the NOS (Leung et al., 2020). To address the misalignment between teachers' beliefs about teaching SSI and the expectations of the SSI paradigm, the following research questions were used to guide this study. (a) What changes, if any, occurred in PSTs' teaching beliefs about SSI during an initial teacher education course on SSI? (b) If changes occurred, which of the course's learning experiences were they associated with?

\section{Methods}

\section{Research Design}

This study adopted a qualitative case study approach (Yin, 2014). During the science teacher education course that formed the context for this study, PSTs' beliefs about teaching SSI were examined by studying their curriculum designs and associated visual representations, lesson plans and reflective journals, to better understand the change in their beliefs over time. This study was conducted in alignment with the Human Research Ethics Committee of the University of Hong Kong (ref. no. EA1801058).

\section{Participants}

The study group comprised 22 PSTs (14 females and 8 males (pseudonyms provided below)) who had enrolled in a credit-bearing course to fulfil the requirements of a fiveyear teacher education programme in science. The participants were in the final year of 
their studies. They had taken science courses in their relevant science majors, general pedagogical courses (e.g. Social and Philosophical Foundations of Education) and discipline-specific pedagogical courses (e.g. Teaching and Learning Science, Practical Work and Scientific Inquiry and Curriculum and Assessment). The participants had received no instruction in SSI pedagogy in their previous courses, making this course new to them.

\section{Context of the Study}

The course adopted a reflection orientation (Abell \& Bryan, 1997) to foster the learning of the PSTs through reflection from both a learner's perspective and a teacher's perspective, as detailed in Appendix 1 (All appendices can be found in the supplementary materials).

Reflection from a Learner's Perspective. This module was guided by key components for critical engagement with SSI, including the NOS and the nature of the media. Many science teachers lack an adequate NOS understanding (Lederman \& Lederman, 2014). In 2008, PSTs in Hong Kong were found to be no exception (Wong, Hodson, Kwan, \& Yung, 2008), and there is no evidence that the situation has changed in the last decade. As a naïve NOS understanding does not allow teachers to offer informed insights into the NOS when teaching SSI (Kilınç et al., 2013), to help the study group develop their NOS understanding, an explicit reflective approach was adopted (Khishfe \& Abd-ElKhalick, 2002). Accordingly, the post box activity modified from Hume (2009) was used (weeks 2 and 3), among other activities. In this activity, a statement related to specific aspects of the NOS was assigned to each of the post boxes, which were arranged around the classroom. The participants posted their views on these statements anonymously in designated post boxes. The statements were presented in a contentious manner to help the participants reflect on their NOS understanding.

As SSI are frequently covered in the news, the news media provide a rich and convenient source of information about SSI. However, it may be risky for students (as consumers of science) and science teachers to use media information if they do not understand how news stories are produced and their limitations (Klosterman, Sadler, \& Brown, 2012). As Höttecke and Allchin (2020) argued, it is essential to extend the current notion of the NOS to a more expansive concept of science-in-society, which reflects the mediation and transformation of scientific discoveries into scientific claims by the media. Therefore, it was important to develop the participants' understanding of science communication from the science community to the public through the media (week 4). In week 5, the participants engaged in a peer discussion to reach a reasoned position on SSI, followed by a self-evaluation, in which they identified the criteria they had considered and those they had not. This discussion served to develop their reasoning on SSI and offered them the opportunity to experience the benefits and challenges of making informed judgements about SSI. Inviting the participants to evaluate their own performance highlighted the importance of multi-perspective evaluation for informed judgements on SSI (Leung, Wong, \& Yung, 2015; Leung \& Cheng, 2020) and the need to close the gap between understanding (e.g. of the NOS and science content knowledge) and its use for SSI evaluation (as emphasised by Leung, 2020b). 
Reflection from a Teacher's Perspective. As SSI teachers need to understand what SSI are, the characteristics of SSI were discussed in week 6 . In week 7, the participants' performance expectations for their critical evaluation of SSI were discussed and theoretical tools supporting student decision-making on SSI were introduced. Next, the participants engaged in a reflective discussion on the place of SSI in the science curriculum (week 8). Various instructional approaches to and methods of assessing SSI were introduced, including one instructional session on the use of modelling as an SSI pedagogy (week 9) and two instructional sessions analysing authentic video footage of teachers covering SSI in HK classrooms (weeks 10 and 11). The course ended with a group presentation activity based on the above video analysis (week 12). The PSTs were assessed based on their group presentations, weekly reflective journal entries and lesson plans.

\section{Data Collection}

To answer Research Question 1, a curriculum design task and a lesson planning task (see Appendices 2 and 3) were administered at various time points to capture the participants' belief changes. To answer Research Question 2, reflective journals were used to reveal the key learning experiences that had shaped the participants' teaching beliefs about SSI.

Curriculum Design. In week 1, week 6 and week 12, the participants were invited to design an 'ideal' science curriculum. They were asked to (a) identify the essential components of a science curriculum and to rank them according to their perceived level of importance, (b) justify their choice and ranking, and (c) visually represent their curriculum design (see Appendix 2). Item (a) showed whether SSI were seen as a key component of the science curriculum, i.e. whether SSI were excluded by the participants' belief filters. Item (b) presented the rationale for the inclusion of SSI, i.e. how SSI were conceptualised by the participants' belief frames. Item (c) provided supporting textual data.

Lesson Plan. The participants were asked to create a lesson plan for secondary school students based on an issue of their choice (see Appendix 3). It was expected that an analysis of the participants' planned actions of SSI teaching would reveal their beliefs about teaching SSI. The task was based on the Content Representation instrument (Loughran, Mulhall, \& Berry, 2004). This task was administered in week 7 and week 12 , but only their week 12 lesson plan was used for analysis, because at week 7, the participants had yet to be exposed to instructional activities involving SSI-based instruction, making this week's lesson plan more formative. The participants' week 12 lesson plans were examined to identify the role assigned to SSI.

Reflective Journal. The participants kept a reflective journal. Their entries included approximately 200 words per week. There were two types of entries: (a) 'freestyle' reflections on that week's class and (b) answers to specific questions. For example, during the curriculum design task in week 6 and week 12, the participants were asked to reflect on their earlier curriculum and lesson plans and how they had been strengthened or changed. 


\section{Data Analysis}

Teaching Beliefs about SSI. The data collected were analysed qualitatively using an inductive method (Peräkylä, 2005). The author and a fellow researcher conducted an iterative analysis process during which they were blinded to the identities of the participants and the time point of data collection. In the first iteration, the two researchers examined the data independently, before meeting to generate a taxonomy that characterised the range of patterns observed in the data set. Next, they returned to the data for another round of independent analysis, during which the data were reexamined based on the emerging themes to develop consensus codes. As the analysis progressed, six teaching belief profiles emerged, falling into three categories: bidirectional view, including theoretical ideal and two-way; unidirectional view, including SSI as a goal, SSI as a vehicle and content interpretation; and traditional view (see Appendix 4). This classification was informed by both the literature and the data collected. Finally, the researchers independently reviewed the data and allocated each participant at each time point to one of the developed profiles. The intercoder reliability for each data source was greater than .90 , as measured by Cohen's kappa coefficient.

Key Learning Experiences. Three participants were selected as illustrative cases to develop a more nuanced understanding of the participants' belief change. Pathways through which the participants had exhibited a shift in beliefs about teaching SSI were characterised, namely a progression and plateau pathway (seven participants), a steady progression pathway (six participants) and a plateau and progression pathway (nine participants). An illustrative case was chosen from each of these three groups. All of the three chosen participants had switched to a theoretical ideal view and had ranked SSI as a priority at the end of the course. Their data were examined to unpack the key learning experiences that had led to the desired shift in their beliefs. These findings revealed areas to focus on in future course design.

Validation strategies were used to ensure the trustworthiness of the results. A colleague from the field of science education was invited to participate as a peer checker in the data analysis to enhance the validity of data interpretation. Detailed descriptions of the methods and raw data in the form of quotations are provided here to allow readers to follow and evaluate the evidentiary basis of the results. As the author was the course instructor, to minimise data trustworthiness problems, data analysis was conducted after the grades had been finalised, and the participant identities were not disclosed to the author before this time.

\section{Results}

\section{Teaching Beliefs About SSI and Changes in These Beliefs}

Table 1 shows the participants' teaching beliefs about SSI in week 1, week 6 and week 12. The data are also presented in Fig. 1. Based on the data collected from the curriculum designs, 18 of the 22 participants held a traditional view in week 1 , believing that neither SSI nor STSE had a place in the science curriculum despite the 


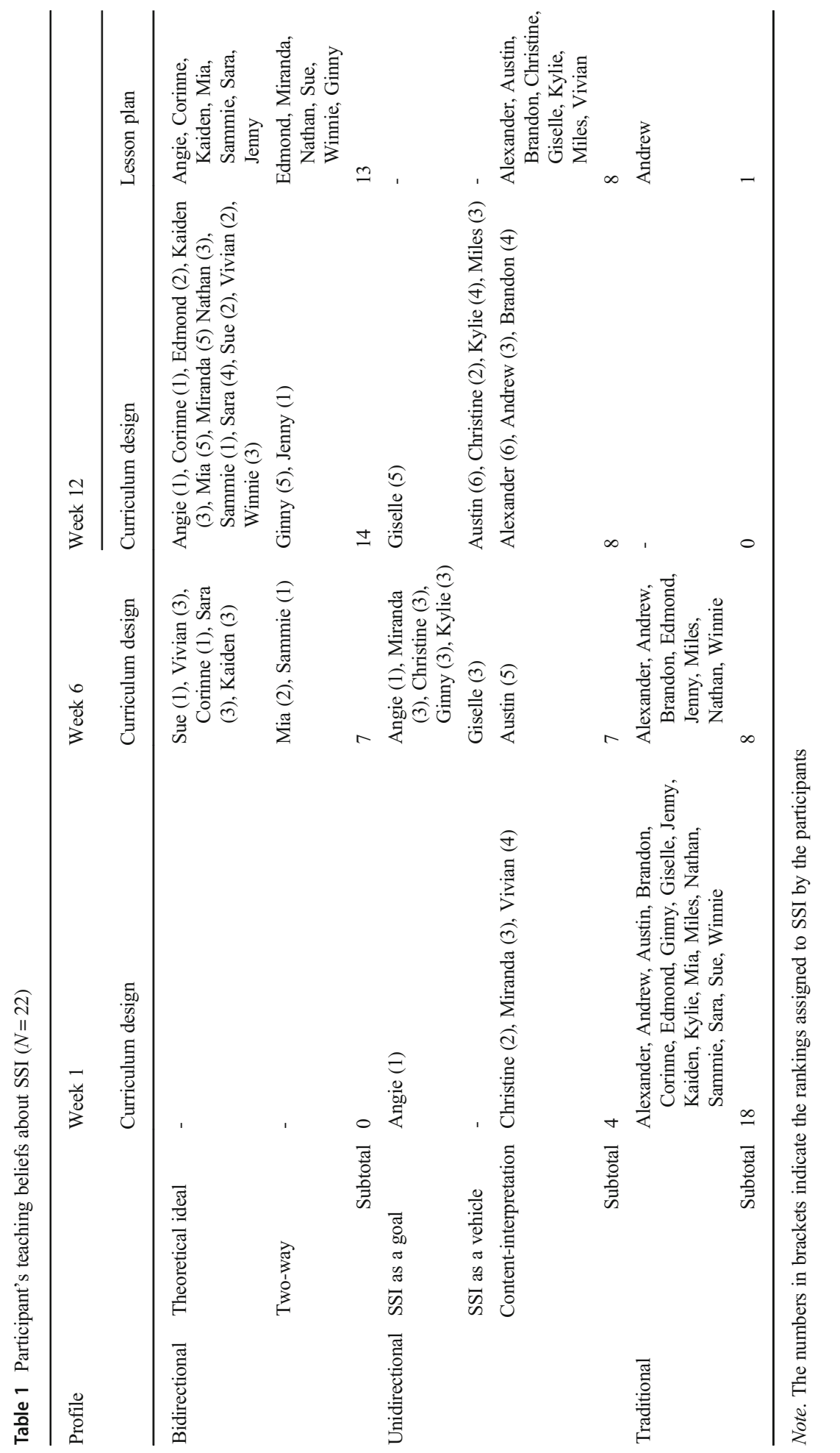




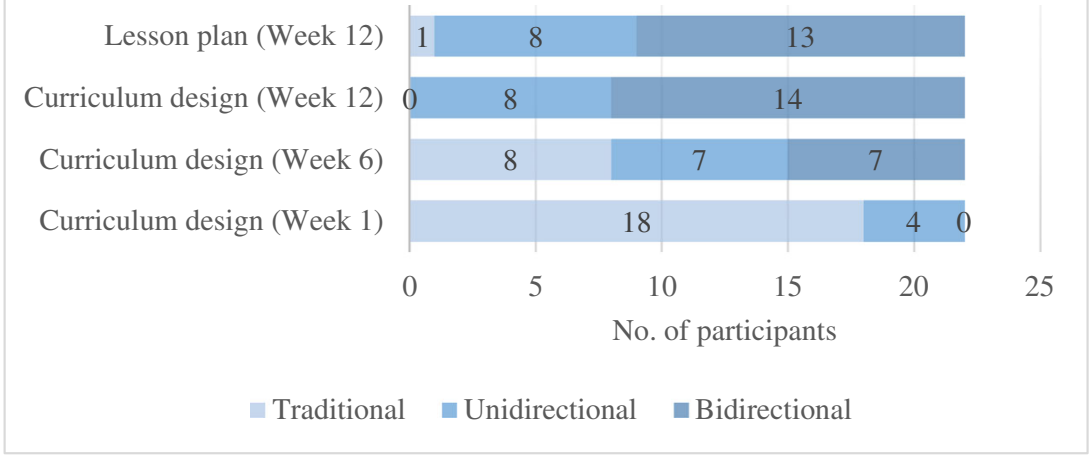

Fig. 1 Participants' teaching beliefs about SSI $(N=22)$

role of STSE in the HK science curriculum. Data analysis suggested that before the course, the participants tended to perceive SSI and STSE as the same, due to their similarities; thus, those who mentioned STSE were considered for further analysis to understand their rationale. Among the four participants who assigned a place to SSI/ STSE, none had a bidirectional view. These reflected the lack of focus on SSI/STSE in the previous courses taken by the participants.

In week 6, seven participants switched to a bidirectional view, with five believing in the theoretical ideal view. Eight of the 22 participants continued to have a traditional view. It should be noted that those with a bidirectional view (i.e. Sue, Corinne and Sammie) were more likely to rank SSI as the most important component of the science curriculum, compared with those with a unidirectional view (i.e. Angie alone). This suggested a possible association between the bidirectional view and the perceived importance of SSI in the science curriculum. In week 12, the number of participants with a bidirectional view increased to 14 and none of the participants had a traditional view, suggesting that at the end of the course, all of the participants recognised the importance of SSI. Similar to the results for week 6, only those with a bidirectional view ranked SSI as a priority in their curriculum design (i.e. Angie, Corinne, Sammie and Jenny) in week 12. A similar distribution was revealed in the participants' lesson plans, with 13 participants with a bidirectional view and 8 with a unidirectional view. Interestingly, one participant (Andrew) produced a lesson plan that suggested a traditional view, although he assigned some importance to SSI, ranking SSI as the third most important curriculum component. Overall, the beliefs reflected in the participants' curriculum designs and lesson plans were generally coherent when classified into the three broad categories of bidirectional, unidirectional and traditional views, except those of Vivian and Andrew. Upon closer examination, this coherence was not observed when the beliefs were further classified into the six fine-grained profiles.

\section{Illustrative Cases}

Corinne. Like most of the participants, Corinne had a traditional view of SSI in week 1, which shifted to a theoretical ideal view in week 6 and remained the same in week 12, following a progression and plateau pathway. She used a 'balloon' model to represent 
her curriculum design in week 1 (see Appendix 5) and added SSI and the NOS to her model in week 6 , as shown in the following excerpt from her reflective journal:

... I have realised the limitations of the old model to develop a holistic [form of] scientific literacy [that is] valued in society... I have figured out how the science curriculum could be restructured in a way that addresses the above-mentioned limitations and I have developed a new model with two new components, SSI and the NOS, ranked at the top with the aim of nurturing socially responsible, inquiry-based and knowledgeable scientific literacy. (Reflective journal, emphasis added)

When reflecting on her 'balloon' model from week 1, Corinne identified its limitations in relation to the goal of 'nurturing socially responsible, inquiry-based and knowledgeable scientific literacy', i.e. why teaching SSI. It was then that she decided to include SSI in her model to overcome these limitations. The following excerpt from her reflective journal reveals how this change happened:

The discussion in Lecture 5 enlightened me regarding the importance of considering not only scientific knowledge or inquiry skills when making decisions, but also other aspects, such as morality and ethics ... I think that exploring SSI with broad criteria, as we did in Lecture 5, should be a priority in the curriculum, to ensure that we are nurturing scientific literacy that will conform to important values in society. (Reflective journal, emphasis added)

Engaging in SSI as learners provided the participants with first-hand experience to understand what students need to make informed judgements about SSI. This experience made Corinne realise the need to consider 'broad criteria', including 'morality and ethics'. This realisation explained her change of belief from the traditional view and her adoption of a value dimension regarding the introduction of SSI in the curriculum. Corinne's week-12 curriculum design still indicated a theoretical ideal view, but she used a different visual representation. Her 'flowchart' model specifically highlighted the interconnection between SSI, content knowledge and the NOS (see Appendix 5). In addition, her decision to adopt the value dimension of SSI teaching was visible in both of her curriculum design and lesson plan:

[SSI] also stress [the importance of] values education, which plays an important role in nurturing students as responsible citizens... [R]ecent reports on the scientist behaviour [are] in conflict with [the] moral standards of society ... [This] reminds us [of] the importance of adhering to sociocultural values while seeking scientific advances. SSI that highlight the social and emotional development of young people [in a] science-related context may indeed be a better alternative than STSE. (Week-12 curriculum design, emphasis added)

Corinne's rationale for prioritising SSI over STSE was based on an emphasis on the value of SSI. This suggested that her understanding of SSI went beyond STSE, 
emphasising 'values education' and 'social and emotional development'. Below are excerpts from her lesson plans that exemplified her change of topic:

I would prepare disassembled components of the DNA model and ask my students to assemble the DNA structure in groups. Then, I [would] ask them to compare the structures so they [could] appreciate the huge number of ways of assembling [the model] and the one... by Watson and Crick [as] one of the many possibilities. (Week-7 lesson plan)

... with this recent authentic controversial news as the scenario, students will be asked to pick a stance and decide whether they would create genetically edited baby to prevent potential HIV infection by imagining that they were the scientists. To develop students' critical thinking skill and their ability to think from multiple perspectives, I will guide them to think about different criteria (e.g., pros and cons to individuals' wellbeing, moral and ethical value and scientific criteria)... (Week-12 lesson plan)

Her lesson planning suggested not only a change of topic, but also a change in lesson objectives. Whereas Corinne's week-7 lesson plan indicated an emphasis on developing students' understanding of the DNA structure and their appreciation of the DNA model by Watson and Crick, her week-12 lesson plan suggested that she had shifted focus to decision-making (i.e. 'pick a stance and decide') through multi-perspective taking (i.e. 'think from multiple perspectives') and the consideration of value judgements (i.e. 'moral and ethical value'). The latter lesson design better exemplified fully fledged SSI teaching. In her reflective journal, Corinne discussed her change of topic in her lesson plan:

The discussion on the definition of SSI convinced me that a good SSI context should not simply be a scientific issue that has social relevance, but preferably carry a highly controversial element and greatly affect society['s] values, such as morality. This encouraged me to switch from DNA discovery to designer babies, with an additional emphasis on morality and ethics... I really like the way we are allowed to refine our design at different stages of our learning. In this way, I am encouraged to reflect on my previous design and to constantly improve or make adjustments based on what I learn throughout the course. (Reflective journal, emphasis added)

Corinne explained that the revised topic better suited the idea of SSI as 'highly controversial' and 'greatly affect[ing] society['s] values'. She attributed this change to the discussion of the definition of SSI. She appreciated the opportunity to reflect on her previous lesson plan, which enabled her to examine how SSI-based teaching should be conducted to 'constantly improve' her design. In summary, Corinne's case suggested that the key learning experiences supporting her shift to the theoretical ideal view were as follows. (a) Being engaged as an SSI learner, which prompted Corinne to reflect on why students should be taught about SSI, the limitations of her previous curriculum design to achieve this goal and what students need to make informed judgements about SSI. Reflecting on the why question made Corinne aware of the importance of teaching SSI to students, while reflecting on the what question led her to 
appreciate the value of teaching SSI to students. (b) Discussing the characteristics of SSI, coupled with the opportunity to revise her previous lesson plans, encouraged Corinne to reflect on how to implement SSI teaching, leading her to change her SSI topic and teaching procedures to ones that were better aligned with the SSI paradigm.

Sammie. Sammie had a traditional view in week 1 , which shifted to a two-way view in week 6 and to a theoretical ideal view in week 12, following a steady progression pathway. Her week-1 curriculum design was largely content-oriented (see Appendix 5), with SSI playing no role. In her week-6 curriculum design, SSI were assigned a place:

I changed my mind about SSI after attending the sample lesson in this course. It convinced me that apart from content knowledge, knowledge of the social context in which we live can be crucial when discussing a science topic... Indeed, seeing the many negative consequences [of] fake science news, such as antivaccination [proponents], it is increasingly important to discuss these issues in the classroom... (Reflective journal, emphasis added)

Similar to Corinne, Sammie reported that her experience as an SSI learner led her to change her beliefs. 'Seeing the many negative consequences [of] fake science news', she was alerted to the growing urgency of engaging students in discussions about SSI. This learner experience prompted her to reflect on why SSI should have a place in the science curriculum. Her response also suggested that her experience as an SSI learner made her realise the need to consider 'knowledge of the social context' in addition to 'content knowledge'. This contributed to her abandonment of the content-oriented curriculum from week 1.

Another important change in Sammie's beliefs between week 1 and week 6 concerned the interrelationship between curriculum components:

Comparing my two curriculum diagrams, another obvious difference is the linear direction from content knowledge to social application, versus an interconnected relationship between content knowledge, SSI and FOS [features of science]. The change occurred to me when I noticed the effect of society on scientific knowledge. (Reflective journal, emphasis added)

Similar to Corinne's week-12 curriculum, Sammie's week-6 curriculum highlighted the interconnection between SSI and other curriculum components. She attributed this to her understanding of the 'effect of society on scientific knowledge', suggesting that NOS may help PSTs develop a two-way view of SSI and other curriculum components. In week 12, Sammie reflected on how her teaching beliefs about SSI had changed:

Analysing the videos of lessons from experienced teachers also challenged my perception of several practices and strategies that I used to support the teaching [of] SSI in my lesson plan design, because I found myself disagree[ing] with some teachers' approaches in the videos, which I frequently adopted in the past. This realisation would not have come to me if I had not analysed them from an 
outsider's point of view, but continued to use them with false assumptions. (Reflective journal, emphasis added)

The video analysis workshop led her to reflect on her past practice 'from an outsider's point of view'. The key learning moment for Sammie was when the videos showed a similar teaching approach to the one she had used in her lesson planning task, with which she no longer agreed. She further described her change as follows:

My understanding of what 'authenticity' means has changed ... watching the videos, I realised that no matter how 'real' the depiction of a fictional case is, the benefits for students will not reach those of news or events that actually happen in the real world and have personal connections with us... [This] may be because students cannot immerse themselves in a fake role... I came to the understanding that... allowing students to make real decisions that represent their own beliefs is essential... (Reflective journal, emphases added)

Sammie's view of 'authenticity' changed from using 'fictional case[s]' to using 'news or event[s] that actually happen in the real world' and from engaging students in playing a 'fake role' in role-play to making 'real decisions that represent their own beliefs'. Sammie's reflection revealed how the analysis of video footage featuring SSI teaching had challenged her practice and led to a change in her teaching beliefs, guiding her pedagogical decisions, as evidenced in the following excerpts from her lesson plans:

I will first introduce some controversial science knowledge about abortion, such as the definition of 'life'. Then, I will split students into groups, where each group is assigned a specific social role and status. By imagining being that stakeholder, students will research on 'their' opinions about abortion and answer two questions... (Week-7 lesson plan)

I will first show students [a] controversial news [item]... Preferably it will be the story of a real mother who struggles to make an abortion decision... After reading the news, students will vote for their initial decision of whether they agree or disagree with legalizing abortion, and some students will be invited to justify [their choice] with reasons... According to [the] students' vote[s], I will split students into groups, where each group is assigned a specific social role and status corresponding to their stance.... (Week-12 lesson plan)

In week 12, Sammie chose to begin the lesson with the controversial news story of a 'real mother' rather than with definitions of life. Whereas her plan in week 7 had been to split students into groups and have each group research a position assigned to them, Sammie now planned to assign students to research groups based on their votes. Sammie's lesson plan thus became more authentic as a result of the change in her teaching beliefs triggered by the analysis of video footage featuring SSI teaching that challenged her practice.

In summary, Sammie's case showed that the key learning experiences explaining her belief change were as follows. (a) Understanding the negative effects of fake science news on judgements about SSI, which led her to realise why it is important to teach SSI; 
(b) being engaged as an SSI learner, which prompted her to reflect on what students need to make informed judgements about SSI and made her realise the need to go beyond content knowledge; and (c) her analysis of videos featuring SSI teaching, which challenged her ideas about teaching practice, i.e. how to implement SSI teaching in a more authentic way.

Angie. In week 1, Angie had a more advanced view than the other participants, as she considered understanding SSI as a goal. Her initial view was reinforced in week 6 and switched to the theoretical ideal view in week 12, following a plateau and progression pathway. Angie used a 'timescale' model to represent her curriculum design in week 1 and week 6 (see Appendix 5). However, a notable change in her visual representation in week 6 was reflected in her focus on science-related issues in the modern world:

My belief in STSE is reinforced, because the dihydrogen monoxide parody discussed in class made me think how silly students would be if they could not apply their scientific knowledge without being fooled by this parody and other false rumours... in the curriculum magnifying glass task, I tried to include STSE in [the] form of a newspaper, which symbolises [the] media as the source that connects the four aspects of STSE, instead of dividing it as in the previous diagram. (Reflective journal, emphasis added)

The dihydrogen monoxide parody was used to demonstrate how readers could easily be misled, despite their understanding of scientific concepts. This reinforced Angie's view of SSI as a goal by leading her to reflect on the reasons why students should learn science, i.e. not to 'be fooled by this parody and other false rumours'. In week 12 , Angie's 'timescale' model changed to a 'warrior' model:

The yellowish light radiating from the centre represents SSI, which can integrate scientific knowledge, scientific inquiry, [the] NOS and STEM [science, technology, engineering and mathematics] education with their contexts in the form of a light surrounding them, and require [an understanding of] scientific knowledge, scientific inquiry and [the] NOS to analyse and evaluate them [and help students] to choose a stance, make informed decisions and take action. (Week-12 curriculum design, emphasis added)

With the use of a 'yellowish light radiating from the centre', her 'warrior' model highlighted the integration of SSI with other curriculum components, which had been absent from her previous curriculum designs. She used the term 'SSI' instead of 'STSE' in her week-12 curriculum design, for the following reasons:

The focus on STSE in the local curriculum lacks the dimensions of moral, ethical and emotional concerns critical to making informed decisions... To consider the holistic growth of future generations, the term 'SSI' is used. (Week-12 curriculum design, emphasis added) 
Angie acknowledged the role of SSI in addressing 'the dimensions of moral, ethical and emotional concerns essential to make informed decisions', which goes beyond that of STSE. This was also reflected in the change to her lesson plan topic, which was the discovery of insulin in week 7, but in week 12 became the question 'to what extent should genetic modification be allowed in humans?':

Active reading [of] a passage on the discovery of insulin and thinking through questions in a worksheet (10 minutes); sharing their responses in pairs (5 minutes); collection and summary of class responses (10 minutes) (Week-7 lesson plan)

Teacher introduces recent news on genetic modification around the world, elicits students' initial ratings and reasoning for the question... (5 minutes); teacher gives guidelines on how to identify the key message (perspectives - social, economic, ethical, etc.) from the article to share (5 minutes); jigsaw reading... students share their ideas in groups, with a focus on the circumstances under which gene modification in humans is acceptable and the reasons for this (15 minutes)...; teacher elicits students' final ratings for the question... and elaborates on the differences between the ratings (5 minutes). (Week-12 lesson plan)

Apart from the change in topic, changes were identified in Angie's teaching procedures. Her week-7 lesson plan mainly involved active reading and group discussions. Her week-12 lesson plan involved engaging students in decisionmaking (e.g. 'initial rating' and 'final rating'), multi-perspective taking (e.g. 'social, economic, ethical') and value judgements (e.g. 'whether some circumstances should be more valued than others'), which were better aligned with fully fledged SSI teaching. Below is an excerpt from her reflective journal about the change to her lesson plan:

this issue [insulin discovery] has little personal connection with students ... SSI [are] usually controversial in nature and have personal meaning for students. This topic does not fit well [with] the definition of SSI... it cannot really empower students as citizens to make informed decisions on issues related to their current lives. (Reflective journal, emphasis added)

Her recognition of SSI as being 'controversial in nature' and having 'personal meaning' helped her think about how to implement SSI teaching for students. This, in turn, guided her pedagogical decision to change her topic and the teaching procedures in her lesson plan.

In summary, Angie's case showed that the key learning experiences leading to her shift were as follows. (a) Discussing the dihydrogen monoxide parody, highlighting the manipulation of readers by the media, which encouraged Angie to reflect on why students should learn about SSI; and (b) discussing the characteristics of SSI, which prompted Angie to think about how to implement SSI teaching, in accordance with these characteristics. 


\section{Discussion}

\section{Research Question 1: Change in Beliefs About SSI Teaching}

This study examined PSTs' teaching beliefs about SSI and the change in these beliefs during a teacher education course, developing profiles characterising these beliefs. In the pre-course, most of the participants had a traditional view, considering SSI as playing no role in science education. Unlike many prior studies reporting overwhelming teacher approval of SSI (e.g. Kara, 2012; Leung et al., 2020), very few of the participants in this study initially assigned SSI/STSE a place in the science curriculum. This was likely due to the different ways in which the participants' ideas and beliefs were obtained. In this study, the participants were not asked whether it is a good idea to teach SSI (i.e. professed beliefs), but invited to design a science curriculum that captured their teaching beliefs about SSI (i.e. intended beliefs). In the post-course, none of the participants reported a traditional view, supporting the use of a reflection orientation to design a course aimed at changing the teaching beliefs about SSI of PSTs. The results also suggest that the participants with a bidirectional view tended to assign more importance to SSI in the science curriculum. This result supports our attempt (Leung et al., 2020) to understand the importance of a bidirectional view of SSI to develop PST beliefs about teaching SSI. That is, a bidirectional view helps PSTs to see how incorporating SSI into the science curriculum can support student learning of SSI and other curriculum components. Otherwise, SSI may be treated as a standalone addon and therefore as a teaching burden.

There is a tension between theory and practice regarding the potential dichotomisation between teaching SSI and teaching conceptual knowledge. Sadler et al. (2006) highlighted the 'false dichotomization of teaching for socioscientific decision-making and teaching for conceptual understanding' (p. 373). However, Forbes and Davis (2008) reported that in practice, this dichotomisation is largely true for PSTs. This study showed that this dichotomisation can be overcome by shifting to a bidirectional view of teaching SSI, i.e. SSI and other curriculum components are not mutually exclusive, but support each other.

\section{Research Question 2: Learning Experiences Associated with the Change in Belief}

The key learning experiences and how they supported a shift to the theoretical ideal view were revealed by the three illustrative cases. The results showed that thinking about the why, what and how of teaching SSI significantly affected the participants' beliefs.

Why Teaching SSI. By highlighting how readers are easily manipulated by fake or biased science-related news (week 4), the study guided the participants to realise the need for students to learn about making informed judgements about these issues. By reflecting on their curriculum designs in response to this need, the participants became aware of the limitations of excluding SSI in their initial curriculum design. In other words, thinking about the why of teaching SSI can allow PSTs to acknowledge the importance of SSI, increasing the likelihood that SSI will go through their belief filters and be assigned a place in the curriculum. 
What to Teach About SSI?. Through their engagement as SSI learners, the participants were able to realise the limitations of over-reliance on hardcore science and the need to consider dimensions beyond science, e.g. values and social perspectives, to inform judgements on SSI (week 5), thereby challenging the value-neutral approach to science education reported in previous studies (e.g. Ekborg, 2013). The rationale for engaging PSTs as SSI learners was to enable them to experience the benefits and challenges of making informed judgements about SSI, as their future students may go through this process. This allowed the participants to identify what is necessary to support students' critical engagement with SSI. This method should prepare PSTs to embrace dimensions beyond hardcore science and may shape their belief frames, i.e. how SSI are conceptualised in their teaching.

How to Teach SSI. PSTs often have limited experience of teaching SSI to students. Thus, the lesson planning task was used to ensure that the participants experienced pedagogical decision-making related to SSI. By reflecting on their own lesson plans (i.e. how to teach SSI), supported by instructional activities, such as analysing authentic video footage featuring students learning about SSI (weeks 10 and 11) and understanding the nature of SSI (week 6), the participants were expected to shape their belief guides for action. Indeed, this method informed their pedagogical decisions on the choice of instructional strategies to make the learning of SSI more authentic, as in the case of Sammie, and on the choice of SSI topics embodying the ethical and moral dimensions of an SSI, as in the cases of Corinne and Angie. In addition, as the local science curriculum is guided by STSE, it is very important to understand the differences between SSI and STSE. For example, PSTs should consider SSI as an alternative to STSE to better meet the need to develop scientifically literate citizens.

This study provides insights into the mindset of PSTs regarding teaching SSI to students in Hong Kong. Using three in-depth illustrative cases, it provided a detailed account of how PST beliefs shifted to the theoretical ideal view during the course. This revealed how a reflective approach focusing on the why, what and how of teaching SSI to students can shape the belief filters, belief frames and belief guides of PSTs. The results may also contribute to initial teacher education programmes in similar contexts to help PSTs incorporate SSI into the curriculum. They are also of value to initial teacher education programmes in places where SSI have been a focus, but have not been adequately substantiated in teacher education (e.g. Genel \& Topçu, 2016; Labate, 2007) or in the classroom (e.g. Ekborg et al., 2013; Tidemand \& Nielsen, 2017). They may guide the design of initial teacher education programmes with a focus on preparing science teachers to teach SSI. By attending to teachers' shifts in beliefs about teaching SSI towards the SSI paradigm, this is more likely to lead teachers to value the role of SSI in the science curriculum and become more willing to embrace SSI in their teaching.

According to the Theory of Planned Behaviour developed by Ajzen and Fishbein (1973), which posits that beliefs are predispositions to actions, it is expected that the change in belief about teaching SSI among the participants will inform their future teaching. However, even with teachers' internal beliefs addressed, it is possible that external constraints may prevent science teachers from teaching SSI. Therefore, to actualise the SSI paradigm in science classes, the shift to the theoretical ideal view should be supported by the development of SSI teaching practices, as described in previous studies (e.g. Bayram-Jacobs et al., 2019; Friedrichsen et al., 2020). Both long- 
term professional development with in-class support, such as the co-creation of materials (Friedrichsen et al., 2020), and short-term professional development, such as the enactment of a single SSI module (Bayram-Jacobs et al., 2019) or the introduction of an SSI approach in two 3-h workshops (Furman et al., 2020), have been shown to play a positive role in teachers' uptake of SSI teaching.

A limitation of this study was that although this study illustrated the initial success of shifting PST beliefs about teaching SSI to the theoretical ideal view through the intervention design, there is no guarantee that these beliefs will manifest in classroom practice. Given the possible inconsistency between teaching beliefs and practice, follow-up studies are needed to examine how PSTs transfer this belief change to their teaching, and how the teaching designs and practices of these teacher participants, who had experienced the desired shift in belief, are connected to their preservice experiences. Another limitation was that this study examined the results of specific instructional activities, which encouraged the participants to reflect on the why, what and how of teaching SSI to students. However, it is not clear whether the changes observed were the result of the specific activities examined or of the combined influence of these activities and previous activities undertaken by the participants.

Teachers need to shift their approach to science teaching from a value-neutral approach to one that incorporates SSI and its social and ethical dimensions, to create a more scientifically literate population in the near future, better able to participate in debates and make informed decisions on SSI than is currently the case. To this end, this study addressed the misalignment between PST beliefs about SSI and the SSI paradigm as a preliminary step towards actualising the theoretical ideal view in conventional classroom practice.

Supplementary Information The online version contains supplementary material available at https://doi.org/ 10.1007/s10763-021-10177-y.

Funding This work is based upon work supported by the Seed Fund for Basic Research program of the University of Hong Kong under Project Code 201711159083.

\section{References}

Abell, S. K., \& Bryan, L. A. (1997). Reconceptualizing the elementary science methods course using a reflection orientation. Journal of Science Teacher Education, 8(3), 153-166. https://oi.org/10.1023/A: 1009483431600.

Aikenhead, G. S. (2006). Science education for everyday life: Evidence-based practice. Teachers College Press.

Aikenhead, G. S. (2007). Expanding the research agenda for scientific literacy. In C. Linder, L. Östman, \& P. Wickman (Eds.), Promoting scientific literacy: Science education research in transaction (pp. 64-71). Geotryckeriet Uppsala.

Ajzen, I., \& Fishbein, M. (1973). Attitudinal and normative variables as predictors of specific behaviors. Journal of Personality and Social Psychology, 27(1), 41-57. https://doi.org/10.1037/h0034440.

Amos, R., Knippels, M., \& Levinson, R. (2020). Socio-scientific inquiry-based learning: Possibilities and challenges for teacher education. In M. Evagorou, J. A. Nielsen, \& J. Dillon (Eds.), Science teacher education for responsible citizenship (pp. 41-61). Springer. https://doi.org/10.1007/978-3-030-40229-7 4.

Basturkmen, H., Loewen, S., \& Ellis, R. (2004). Teachers' stated beliefs about incidental focus on form and their classroom practices. Applied Linguistics, 25(2), 243-272. https://doi.org/10.1093/applin/25.2.243. 
Bayram-Jacobs, D., Henze, I., Evagorou, M., Shwartz, Y., Aschim, E. L., Alcaraz-Dominguez, S., Barajas, M., \& Dagan, E. (2019). Science teachers' pedagogical content knowledge development during enactment of socioscientific curriculum materials. Journal of Research in Science Teaching, 56(9), 1207-1233. https://doi.org/10.1002/tea.21550.

Bencze, L., Sperling, E., \& Carter, L. (2012). Students' research-informed socio-scientific activism: Re/visions for a sustainable future. Research in Science Education, 42(1), 129-148. https://doi.org/10.1007/s11165011-9260-3.

Bryan, L. A., \& Atwater, M. M. (2002). Teacher beliefs and cultural models: A challenge for science teacher preparation programs. Science Education, 86(6), 821-839. https://doi.org/10.1002/sce.10043.

Cheng, M. M. W. \& Leung, J. S. C. (in press). Socioscientific issues as a STEM education approach. In M. A. Peters (Ed.), Encyclopedia of teacher education. Springer.

Christenson, N., \& Chang Rundgren, S. N. (2015). A framework for teachers' assessment of socio-scientific argumentation: An example using the GMO issue. Journal of Biological Education, 49(2), 204-212. https://doi.org/10.1080/00219266.2014.923486.

Cohen, R., Zafrani, E., \& Yarden, A. (2020). Science teachers as proponents of socio-scientific inquiry-based learning: From professional development to classroom enactment. In M. Evagorou, J. A. Nielsen, \& J. Dillon (Eds.), Science teacher education for responsible citizenship (pp. 117-132). Springer. https://doi. org/10.1007/978-3-030-40229-7_8.

Curriculum Development Council. (2017). Science education key learning area curriculum guide (primary 1secondary 6). https://www.edb.gov.hk/en/curriculum-development/kla/science-edu/curriculumdocuments.html

Dawson, V., \& Carson, K. (2020). Introducing argumentation about climate change socioscientific issues in a disadvantaged school. Research in Science Education, 50(3), 863-883. https://doi.org/10.1007/s11165018-9715-x.

Ekborg, M., Ottander, C., Silfver, E., \& Simon, S. (2013). Teachers' experience of working with socioscientific issues: A large scale and in depth study. Research in Science Education, 43(2), 599-617. https:// doi.org/10.1007/s11165-011-9279-5.

Evagorou, M., \& Dillon, J. (2020). Introduction: Socio-scientific issues as promoting responsible citizenship and the relevance of science. In M. Evagorou, J. A. Nielsen, \& J. Dillon (Eds.), Science teacher education for responsible citizenship (pp. 1-11). Springer. https://doi.org/10.1007/978-3-030-40229-7_1.

Fang, S. C., Hsu, Y. S., \& Lin, S. S. (2019). Conceptualizing socioscientific decision making from a review of research in science education. International Journal of Science and Mathematics Education, 17(3), 427448. https://doi.org/10.1007/s10763-018-9890-2.

Fives, H., \& Buehl, M. M. (2012). Spring cleaning for the "messy" construct of teachers' beliefs: What are they? Which have been examined? What can they tell us? In K. R. Harris, S. Graham, T. Urdan, S. Graham, J. M. Royer, \& M. Zeidner (Eds.), APA educational psychology handbook, vol 2: Individual differences and cultural and contextual factors (pp. 471-499). American Psychological Association. https://doi.org/10.1037/13274-019.

Forbes, C. T., \& Davis, E. A. (2008). Exploring preservice elementary teachers' critique and adaptation of science curriculum materials in respect to socioscientific issues. Science \& Education, 17(8-9), 829-854. https://doi.org/10.1007/s11191-007-9080-z.

Fowler, S. R., Zeidler, D. L., \& Sadler, T. D. (2009). Moral sensitivity in the context of socioscientific issues in high school science students. International Journal of Science Education, 31(2), 279-296. https://oi. org/10.1080/09500690701787909.

Friedrichsen, P. J., Sadler, T. D., \& Zangori, L. (2020). Supporting teachers in the design and enactment of socio-scientific issue-based teaching in the USA. In M. Evagorou, J. A. Nielsen, \& J. Dillon (Eds.), Science teacher education for responsible citizenship (pp. 85-99). Springer. https://doi.org/10.1007/9783-030-40229-7_6.

Furman, M., Taylor, I., Luzuriaga, M., \& Podestá, M. E. (2020). Getting ready to work with socio-scientific issues in the classroom: A study with argentine teachers. In M. Evagorou, J. A. Nielsen, \& J. Dillon (Eds.), Science teacher education for responsible citizenship (pp. 133-151). Springer. https://doi.org/10. 1007/978-3-030-40229-7_9.

Genel, A., \& Topçu, M. S. (2016). Turkish preservice science teachers' socioscientific issues-based teaching practices in middle school science classrooms. Research in Science \& Technological Education, 34(1), 105-123. https://doi.org/10.1080/02635143.2015.1124847.

Hancock, E. S., \& Gallard, A. J. (2004). Preservice science teachers' beliefs about teaching and learning: The influence of K-12 field experiences. Journal of Science Teacher Education, 15(4), 281-291. https://doi. org/10.1023/B:JSTE.0000048331.17407.f5. 
Hart, E. P. (1989). Toward renewal of science education: A case study of curriculum policy development. Science Education, 73(5), 607-634. https://doi.org/10.1002/sce.3730730508.

Hermans, R., van Braak, J., \& Van Keer, H. (2008). Development of the beliefs about primary education scale: Distinguishing a developmental and transmissive dimension. Teaching and Teacher Education, 24(1), 127-139. https://doi.org/10.1016/j.tate.2006.11.007.

Hodson, D. (2003). Time for action: Science education for an alternative future. International Journal of Science Education, 25(6), 645-670. https://doi.org/10.1080/09500690305021.

Höttecke, D., \& Allchin, D. (2020). Reconceptualizing nature-of-science education in the age of social media. Science Education, 104(4), 641-666. https://doi.org/10.1002/sce.21575.

Hume, A. (2009). Authentic scientific inquiry and school science. Teaching Science, 55(2), 35-41.

Jones, M. G., \& Carter, G. (2007). Science teacher attitudes and beliefs. In S. K. Abell \& N. G. Lederman (Eds.), Handbook of research on science education (pp. 1067-1104). Lawrence Erlbaum Associates.

Kara, Y. (2012). Pre-service biology teachers' perceptions on the instruction of socio-scientific issues in the curriculum. European Journal of Teacher Education, 35(1), 111-129. https://doi.org/10.1080/02619768. 2011.633999.

Karisan, D., \& Zeidler, D. L. (2017). Contextualization of nature of science within the socioscientific issues framework: A review of research. International Journal of Education in Mathematics, Science and Technology, 5(2), 139-152.

Karpudewan, M., \& Roth, W. M. (2018). Changes in primary students' informal reasoning during an environment-related curriculum on socio-scientific issues. International Journal of Science and Mathematics Education, 16(3), 401-419. https://doi.org/10.1007/s10763-016-9787-x.

Khishfe, R., \& Abd-El-Khalick, F. (2002). Influence of explicit and reflective versus implicit inquiry-oriented instruction on sixth graders' views of nature of science. Journal of Research in Science Teaching, 39(7), 551-578. https://doi.org/10.1002/tea.10036.

Kim, G., Ko, Y., \& Lee, H. (2020). The effects of community-based socioscientific issues program (SSICOMM) on promoting students' sense of place and character as citizens. International Journal of Science and Mathematics Education, 18(3), 399-418. https://doi.org/10.1007/s10763-019-09976-1.

Kılınç, A., Kartal, T., Eroğlu, B., Demiral, Ü., Afacan, Ö., Polat, D., Demirci Guler, M. P., \& Görgülü, Ö. (2013). Preservice science teachers' efficacy regarding a socioscientific issue: A belief system approach. Research in Science Education, 43(6), 2455-2475. https://doi.org/10.1007/s11165-013-9368-8.

Klosterman, M. L., Sadler, T. D., \& Brown, J. (2012). Science teachers' use of mass media to address socioscientific and sustainability issues. Research in Science Education, 42(1), 51-74. https://doi.org/10.1007/ s11165-011-9256-z.

Labate, H. (2007). Science education: A (pending) chapter in the curriculum transformation in Argentina. PROSPECTS, 37(4), 469-488. https://doi.org/10.1007/s11125-008-9045-2.

Lederman, N. G., \& Lederman, J. S. (2014). Research on teaching and learning of nature of science. In N. G. Lederman \& S. K. Abell (Eds.), Handbook of research on science education (Vol. 2, pp. 600-620). Routledge.

Lee, H., Abd-El-Khalick, F., \& Choi, K. (2006). Korean science teachers' perceptions of the introduction of socio-scientific issues into the science curriculum. Canadian Journal of Math, Science \& Technology Education, 6(2), 97-117. https://doi.org/10.1080/14926150609556691.

Lee, H., Chang, H., Choi, K., Kim, S. W., \& Zeidler, D. L. (2012). Developing character and values for global citizens: Analysis of pre-service science teachers' moral reasoning on socioscientific issues. International Journal of Science Education, 34(6), 925-953. https://doi.org/10.1080/09500693.2011.625505.

Lee, H., \& Witz, K. G. (2009). Science teachers' inspiration for teaching socioscientific issues (SSI): Disconnection with reform efforts. International Journal of Science Education, 31(7), 931-960. https:// doi.org/10.1080/09500690801898903.

Leung, J. S. C. (2020a). Students' adherences to epistemic understanding in evaluating scientific claims. Science Education, 104(2), 164-192. https://doi.org/10.1002/sce.21563.

Leung, J. S. C. (2020b). A practice-based approach to learning nature of science through socioscientific issues. Research in Science Education. https://doi.org/10.1007/s11165-020-09942-w.

Leung, J. S. C., Wong, A. S. L., \& Yung, B. H. W. (2017). Evaluation of science in the media by non-science majors. International Journal of Science Education, Part B, 7(3), 219-236. https://doi.org/10.1080/ 21548455.2016.1206983.

Leung, J. S. C., Wong, A. S. L., \& Yung, B. H. W. (2015). Understandings of nature of science and multiple perspective evaluation of science news by non-science majors. Science \& Education, 24(7), 887-912. https://doi.org/10.1007/s11191-014-9736-4.

Leung, J. S. C., \& Cheng, M. M. W. (2021). Trust in the time of corona - epistemic practice beyond hard evidence. Cultural Studies of Science Education. https://doi.org/10.1007/s11422-021-10045-9. 
Leung, J. S. C., Wong K. L., \& Chan, K. K. H. (2020). Pre-service secondary science teachers' beliefs about teaching socio-scientific issues. In J. Dillon, M. Evagorou \& J. A. Nielsen (Eds.), Science teacher education for responsible citizenship (pp. 21-39). Springer. https://doi.org/10.1007/978-3-030-402297_3.

Leung, J. S. C., \& Cheng, M. M. W. (2020). Conceptual change in socioscientific issues: Learning about obesity. International Journal of Science Education, 42(18), 3134-3158. https://doi.org/10.1080/ 09500693.2020.1856966.

Loughran, J., Mulhall, P., \& Berry, A. (2004). In search of pedagogical content knowledge in science: Developing ways of articulating and documenting professional practice. Journal of Research in Science Teaching, 41(4), 370-391. https://doi.org/10.1002/tea.20007.

Newton, M. H., \& Zeidler, D. L. (2020). Developing socioscientific perspective taking. International Journal of Science Education, 42(8), 1302-1319. https://doi.org/10.1080/09500693.2020.1756515.

Nuangchalerm, P. (2010). Engaging students to perceive nature of science through socioscientific issues-based instruction. European Journal of Social Sciences, 13(1), 34-37.

Pajares, M. F. (1992). Teachers' beliefs and educational research: Cleaning up a messy construct. Review of Educational Research, 62(3), 307-332. https://doi.org/10.3102/00346543062003307.

Pedersen, J. E., \& Totten, S. (2001). Beliefs of science teachers toward the teaching of science/technological/ social issues: Are we addressing national standards? Bulletin of Science, Technology \& Society, 21(5), 376-393. https://doi.org/10.1177/027046760102100507.

Peräkylä, A. (2005). Analyzing talk and text. In N. K. Denzin \& Y. S. Lincoln (Eds.), The Sage handbook of qualitative research (3rd ed., pp. 869-886). SAGE.

Pitiporntapin, S., Yutakom, N., \& Sadler, T. D. (2016). Thai pre-service science teachers' struggles in using socioscientific issues (SSIs) during practicum. Asia-Pacific Forum on Science Learning and Teaching, $17(2), 1-20$.

Rimm-Kaufman, S. E., Storm, M. D., Sawyer, B. E., Pianta, R. C., \& LaParo, K. M. (2006). The teacher belief Q-Sort: A measure of teachers' priorities in relation to disciplinary practices, teaching practices, and beliefs about children. Journal of School Psychology, 44(2), 141-165. https://doi.org/10.1016/j.jsp.2006. 01.003 .

Roberts, D. A. (2007). Scientific literacy/science literacy. In S. K. Abell \& N. G. Lederman (Eds.), Handbook of research on science education (pp. 729-780). Lawrence Erlbaum.

Rubba, P. A. (1989). An investigation of the semantic meaning assigned to concepts affiliated with STS education and of STS instructional practices among a sample of exemplary science teachers. Journal of Research in Science Teaching, 26(8), 687-702. https://doi.org/10.1002/tea.3660260805.

Sadler, T. D., Amirshokoohi, A., Kazempour, M., \& Allspaw, K. M. (2006). Socioscience and ethics in science classrooms: Teacher perspectives and strategies. Journal of Research in Science Teaching, 43(4), 353-376. https://doi.org/10.1002/tea.20142.

Sadler, T. D., Romine, W. L., \& Topçu, M. S. (2016). Learning science content through socio-scientific issues-based instruction: A multi-level assessment study. International Journal of Science Education, 38(10), 1622-1635. https://doi.org/10.1080/09500693.2016.1204481.

Simonneaux, L., \& Simonneaux, J. (2009). Socio-scientific reasoning influenced by identities. Cultural Studies of Science Education, 4(3), 705-711.

Sjöström, J., \& Eilks, I. (2018). Reconsidering different visions of scientific literacy and science education based on the concept of Bildung. In Y. Dori, Z. Mevarech, \& D. Baker (Eds.), Cognition, metacognition, and culture in STEM education. Innovations in science education and technology (pp. 65-88). Springer.

Tidemand, S., \& Nielsen, J. A. (2017). The role of socioscientific issues in biology teaching: From the perspective of teachers. International Journal of Science Education, 39(1), 44-61. https://doi.org/10. 1080/09500693.2016.1264644.

Topçu, M. S., Foulk, J. A., Sadler, T. D., Pitiporntapin, S., \& Atabey, N. (2018). The classroom observation protocol for socioscientific issue-based instruction: Development and implementation of a new research tool. Research in Science and Technological Education, 36(3), 302-323. https://doi.org/10.1080/ 02635143.2017.1399353.

van Driel, J. H., Bulte, A. M. W., \& Verloop, N. (2005). The conceptions of chemistry teachers about teaching and learning in the context of a curriculum innovation. International Journal of Science Education, 27(3), 303-322. https://doi.org/10.1080/09500690412331314487.

Wang, H. H., Chen, H. T., Lin, H. S., Huang, Y. N., \& Hong, Z. R. (2017). Longitudinal study of a cooperation-driven, socio-scientific issue intervention on promoting students' critical thinking and selfregulation in learning science. International Journal of Science Education, 39(15), 2002-2026. https:// doi.org/10.1080/09500693.2017.1357087. 
Witz, K. G., \& Lee, H. (2009). Science as an ideal: Teachers' orientations to science and science education reform. Journal of Curriculum Studies, 41(3), 409-431. https://doi.org/10.1080/00220270802165640.

Wong, S. L., Hodson, D., Kwan, J., \& Yung, B. H. W. (2008). Turning crisis into opportunity: Enhancing student-teachers' understanding of nature of science and scientific inquiry through a case study of the scientific research in severe acute respiratory syndrome. International Journal of Science Education, 30(11), 1417-1439. https://doi.org/10.1080/09500690701528808.

Wong, S. L., Kwan, J., Hodson, D., \& Yung, B. H. W. (2009). Turning crisis into opportunity: Nature of science and scientific inquiry as illustrated in the scientific research on severe acute respiratory syndrome. Science \& Education, 18(1), 95-118. https://doi.org/10.1007/s11191-007-9123-5.

Yahaya, J. M., Zain, A. N. M., \& Karpudewan, M. (2015). The effects of socio-scientific instruction on preservice teachers' sense of efficacy for learning and teaching controversial family health issues. International Journal of Science and Mathematics Education, 13(2), 467-491. https://doi.org/10.1007/ s10763-014-9537-x.

Yin, R. K. (2014). Case study research: Design and methods (applied social research methods). SAGE.

Yore, L. D. (2012). Science literacy for all: More than a slogan, logo, or rally flag! In K. Tan \& M. Kim (Eds.), Issues and challenges in science education research (pp. 5-23). Springer. https://doi.org/10.1007/978-94007-3980-2 2.

Zangori, L., Peel, A., Kinslow, A., Friedrichsen, P., \& Sadler, T. D. (2017). Student development of modelbased reasoning about carbon cycling and climate change in a socio-scientific issues unit. Journal of Research in Science Teaching, 54(10), 1249-1273. https://doi.org/10.1002/tea.21404.

Zeidler, D. L. (2014). Socioscientific issues as a curriculum emphasis: Theory, research, and practice. In N. G. Lederman \& S. K. Abell (Eds.), Handbook of research on science education (Vol. 2, pp. 697-726). Routledge.

Zeidler, D. L., \& Keefer, M. (2003). The role of moral reasoning and the status of socioscientific issues in science education: Philosophical, psychological and pedagogical considerations. In D. L. Zeidler (Ed.), The role of moral reasoning and discourse on socioscientific issues in science education (pp. 7-38). Kluwer.

Zeidler, D. L., Walker, K. A., Ackett, W. A., \& Simmons, M. L. (2002). Tangled up in views: Beliefs in the nature of science and responses to socioscientific dilemmas. Science Education, 86(3), 343-367. https:// doi.org/10.1002/sce.10025.

Zeidler, D. L., Sadler, T. D., Applebaum, S., \& Callahan, B. E. (2009). Advancing reflective judgment through socioscientific issues. Journal of Research in Science Teaching, 46(1), 74-101. https://doi.org/10. 1002/tea.20281.

Zeidler, D. L., Applebaum, S. M., \& Sadler, T. D. (2011). Enacting a socioscientific issues classroom: Transformative transformations. In T. D. Sadler (Ed.), Socioscientific issues in the classroom (pp. 277305). Springer. 